\title{
Quality Profile Questions of PGSD Students in Learning
}

\author{
Harti Kartini ${ }^{\mathrm{a}}$, Sri Estu Winahyu ${ }^{\mathrm{b}}$, Yuniawatika ${ }^{\mathrm{c}}$, Lilik Bintartik ${ }^{\mathrm{d}}$ \\ PGSD, FIP Universitas Negeri Malang, \\ Malang, Indonesia \\ Corresponding e-mail: aharti.kartini.fip@um.ac.id, bsri.estu.winahyu.fip@um.ac.id, cyuniawatika.fip@um.ac.id, \\ dilik.bintartik.fip@um.ac.id
}

\begin{abstract}
The aim of this study is to describe the profile of PGSD student questions in terms of type and quality. The study was conducted with a quantitative descriptive design. Samples are PGSD students in 2014 and 2015. Samples from 7 offerings totaling 264 students consisting of 56 men and 208 women were determined by stratified non proportional random sampling technique. Data were collected through observation with observation guidance instrument. The collected data is analyzed with descriptive statistics, presented in the form of tables and diagrams. The results show that most of the questions are asked by what question, how, and why. Most of the questions asked by students are low level and submitted by female students. High-level questions raised between male students and women appear balanced. There are still students who ask but do not use the word question. It is suggested to lecturers to give opportunity to ask in writing so that less courageous students ask to participate actively. In addition, lecturers should give examples and train students to ask productive questions that demand answers in the form of proof.
\end{abstract}

Keywords: $\quad$ question, PGSD students.

\section{INTRODUCTION}

The curriculum was one of the guidelines or reference units of education used to achieve the expected educational objectives. Curriculum 2013 is a curriculum applied in Indonesia gradually starting in the academic year 2013/2014 to date. The current 2013 curriculum has been used in 9322 primary schools (SD) spread over 34 provinces in Indonesia. The amount consists of 2,524 government primary schools and 6,808 primary schools that independently volunteered to implement the 2013 Curriculum (Kemdikbud, 2015). Particularly in Malang, all primary schools are set using the Curriculum 2013. According to Majid (2014: 35) there is a fundamental difference in the Curriculum 2013 with the previous curriculum that is on the competency standards of graduates, process standards, content standards, and assessment standards.

One of the fundamental differences in the Curriculum 2013 is the standard process. As stated in Permendikbud No. 65 of 2013 on the standard of basic and secondary education processes that the learning process in Curriculum 2013 for all levels of education implemented using a scientific approach (Scientific). The scientific approach is a scientific approach that aims to guide students in learning by experiencing / finding independently or in groups to build student understanding and train high-level thinking students. The scientific approach in learning encourages students to perform scientific skills, including observing, questioning, trying / gathering information, reasoning / processing information, and communicating (Kemendikbud, 2013:8).

Questioning is one of the scientific approaches in thematic learning based on the Curriculum 2013. Students will carry out question-making activities and determine the answers to what is seen, heard, perceived, listened to, and read in writing or orally. Questioning activities need to be developed by the teacher so that students have a high curiosity attitude and try to find answers based on the questions that have been made. Cunningham (1971) states that "questions are used to give directions, correct misbehavior, manage classroom activity, initiate instruction, create learning situations, and evaluate learning". Questions can be used to encourage students reasoning and activities. Elstgeest (1987) states "The right question asks children to show rather than to say the answer". Ideally this questioning activity should be implemented, but the reality is not the case. Most students find it difficult to convey questions, this is because students are not accustomed and teachers are less likely to give students the opportunity to ask questions (Kartini, et al., 2003). Students are more often positioned as answering teacher questions. If this is left continuously it will be detrimental to the student.

On the other hand, the State University of Malang (UM) as one of the educational institutions has various departments and study programs (Prodi) in charge of giving birth to prospective professional educators. Especially the Prodi PGSD (Primary School Teacher Education) is tasked with giving birth to elementary school teachers who later apply the Curriculum 2013 to take responsibility for 
preparing its students. For that they need to be equipped with knowledge and skills that suit the needs in the field. Among them is preparing them to have the ability to ask questions.

The questions that students ask during the lecture are a reflection of critical attitude and the distribution of curiosity. By analyzing the type and quality of questions asked by students, will be known the ability to ask questions of PGSD students as well as their difficulties in studying lectures. It can be used as information for lecturers to reconstruct the appropriate learning process, so that can be obtained optimal learning outcomes and the ability to ask questions PGSD students can develop.

A review of this question profile is conducted with the general aim of describing the profile of PGSD student questions in terms of gender, type, and quality. In particular the purpose of this study is to identify and describe the types of questions posed by PGSD students in lectures based on question words used; Describes the quality of PGSD student questions based on the level of thinking ability.

\section{METHOD}

This research uses quantitative descriptive design. Population in this research is student of Elementary School Teacher Education (PGSD) Faculty of Education Science (FIP) State University of Malang (UM) which follow lecture at Campus PP2 Malang. Students of PGSD as population come from 2 generation: year 2014 and 2015, amounting to 8 offering that is: A4, B4, C4, D4, A5, B5, C5, D5. Some students were assigned as samples with stratified non proportional random sampling technique.

Stratified sample determination is done on the grounds that the population consists of subpopulations derived from two levels (2014 and 2015). Nonproportional techniques are used because sampling from each subpopulation is randomly determined without taking into account the number of each subpopulation. Randomization is then performed to determine the class or offering and the courses observed. For the selected offering, all students in the offering are determined as a sample. With this technique, a sample of 7 students were selected, consisting of 56 male students $(21.21 \%)$ and female students $208(78.79 \%)$.

To obtain data used data collection instruments and data analysis, namely: blanks and observation guidelines and assessment guidelines. Observation zones are used to record the questions that students have to say in lectures. Observation guidelines are used to analyze the questions asked by the respondent and classify the data. With these instruments can be obtained classification of data based on the type of question, the quality of questions, and the gender of the questioner. Assessment guidelines are used to assess classification data which are then used for interpretation and conclusion.

The main data of this research is the question asked by the students in the lecture at PGSD. Data obtained by observation during the lecture took place. For this purpose, the research team assigns a student of course subjects assigned to record the data and record it in the prepared observation form. The data are recorded in the form of subject names, lecturers' names, offering, number of male students, women, and questions asked. Furthermore, any questions asked by students during the course are recorded. This activity is held several times a meeting for each offering of the course that has been determined.

The questions collected are then identified by type of use of the word question and the level of thought process (question quality). Identification of data is done by giving a specific code (coding). Classification by grouping similar data. Furthermore each classification is analyzed and interpreted based on the theory referred to. The interpretation results are used to draw the conclusions and describe the profile of the questions asked by the students in the lectures at PGSD.

\section{RESULTS}

In general from the results of the analysis of student questions obtained the findings that every lecture takes place, lecturers always provide opportunities for students to ask questions and opportunities are used by students. It is evident that no lectures are recorded without question from students. Every lecture that is observed is always there who ask at least 2 questions asked by students in one course of 40 participants of the lecture. On the other hand the number of questions asked reached 39 questions when the number of students is only 35 . This means there are students who ask more than one question. In general the number of questions that arise from each offering is about 3 to 13 questions.

After further study, it was found that there were three models of questioning by lecturers during lectures. First, the lecturers open the opportunity to ask students without limitation. In such a situation the number of students who ask a little, the questions that appear very little, 2 - 5 pieces. The second model is the student assigned to the presentation and at the end of the session is opened the question for two terms, each term given 3 question opportunity. The average question is 6 pieces. While the third model is the lecturer gives the opportunity to students to write questions before the presentation is done about the material to be studied. Learning with this third model produced many questions asked, because it requires every student to ask in writing. Even the number of questions asked exceeds the number of questioners, because each questioner is allowed to ask more than one question. From the data above this condition 
occurred in the Education Evaluation course which was attended by 35 students, but the question asked by students reached 39 questions.

The results of coding and analysis of student questions based on the use of the word questionnaire obtained the finding that almost all question words are used by students in asking questions (Table. 1). The question word is referred to as $5 \mathrm{~W} 1 \mathrm{H}$ : what, who, when, where, why, and how (what, who, when, where, why, and how).

Table 1. Data Use of Questions in Questions Asked Students PGSD FIP UM During Lectures

\begin{tabular}{ccccccccc}
\hline Course Name & What & Who & Where & When & Why & How & Others & Total \\
\hline PKR & 4 & 0 & 0 & 0 & 0 & 4 & 1 & 9 \\
Pembel. IPS SD & 2 & 0 & 1 & 0 & 0 & 0 & 0 & 3 \\
Pengelolaan Perpus & 5 & 0 & 0 & 2 & 0 & 2 & 0 & 9 \\
Pembel PPKn & 2 & 0 & 0 & 0 & 1 & 3 & 0 & 6 \\
Pembel. IPA di SD & 1 & 0 & 0 & 0 & 0 & 1 & 0 & 2 \\
Met. Penel. Pend & 3 & 0 & 0 & 0 & 0 & 1 & 1 & 5 \\
Met. Penel. Pend & 4 & 0 & 0 & 0 & 0 & 1 & 0 & 5 \\
Evaluasi Pend & 23 & 0 & 0 & 0 & 2 & 8 & 6 & 39 \\
Evaluasi Pend & 5 & 0 & 0 & 0 & 0 & 1 & 3 & 9 \\
TPKI & 8 & 0 & 1 & 0 & 1 & 1 & 0 & 11 \\
PKn & 9 & 0 & 1 & 0 & 0 & 2 & 0 & 12 \\
Geometri \& Penguk. & 1 & 0 & 0 & 0 & 1 & 0 & 1 & 3 \\
Manajemen Kelas & 4 & 0 & 0 & 1 & 1 & 6 & 0 & 12 \\
Pengemb. Pembel & 0 & 0 & 0 & 0 & 1 & 3 & 0 & 4 \\
Pend. Inklusi di SD & 3 & 0 & 0 & 0 & 1 & 4 & 1 & 9 \\
\hline Sum & 74 & 0 & 3 & 3 & 8 & 37 & 13 & 138 \\
\hline Percentage (\%) & 53,62 & 0 & 2,17 & 2,17 & 5,80 & 26,81 & 9,42 &
\end{tabular}

The data in table 1 shows none of the questions asked with the question "who". This is followed by the use of "where and when" queries which contained only 3 questions each $(2.17 \%)$.

Interesting finding from the data above that there are two types of question words that are widely used by students. More than half used question "what" reach 74 pieces $(53,62 \%)$, followed by question "how" reach 26,81\%. Other findings are interesting enough that there are still students who were given the opportunity to ask but did not ask questions but instead ordered or ordered the group to explain something to be known and the number reached $9.42 \%$.

Judging from the quality, student questions are grouped into six categories: knowledge, understanding, application, analysis, evaluation, creation. Of the six categories above can be simplified classification into two, namely low-level questions and high-level questions. The use of "what, who, where, when" questions are classified as lowlevel questions, while the use of "how and why" queries is a high-level question

Knowledge category question with the question "what" is the most question $(53,62 \%)$ submitted by student (table 1), while the question word "where" and "when" only $2.17 \%$ each. The results showed that none of the students used the question "who". The category of knowledge question is classified as a low-order thinking because it only requires an answer that is memorizing / recalling something that has been learned. The understanding question has a higher level of quality than the knowledge type question, because it demands the organization of information, also describes the demand for interpretation of the observed object, whether it is factual phenomenon or table / data table information. The question sentence for this stage is for example using the question "why", "what is the difference between the isolator and the conductor?", "What is the relationship between the fabric type with the absorption?".

The implementation question reveals the intention of the asker to get an explanation of a particular way or criterion and requires a person to apply his knowledge to another situation. Level of analysis questions are expressed with the aim of obtaining clarity about a matter related to the facts related to the problem, also demanding evidence related to the object to be studied more deeply. In this study this type of question is revealed through the question "how" which amounted to $26.81 \%$. The question of synthesis level involves not only supporting facts or causes, but already involving imagination or logical thinking for future events. Example question: "what will happen if the learning in the classroom only uses the lecture method?". The evaluation question is a high-level question, as it demands an opinion that is accompanied by a logical reason. For evaluation questions involving students' abilities in analysis and synthesis.

The data of this study are then distinguished based on the quality of the questions asked by the students that are categorized into low-level questions and high-level questions can be seen in Table 2 and Table 3 . 
Table 2. Distribution Picture Low Level Questions Asked by Students during Lectures

\begin{tabular}{|c|c|c|c|c|c|c|c|c|c|c|c|}
\hline \multirow{3}{*}{ Courses Name } & \multicolumn{8}{|c|}{ Type of asked Questions } & \multirow{2}{*}{\multicolumn{3}{|c|}{ Summary }} \\
\hline & \multicolumn{2}{|c|}{ What } & \multicolumn{2}{|c|}{ Who } & \multicolumn{2}{|c|}{ Where } & \multicolumn{2}{|c|}{ When } & & & \\
\hline & $\mathrm{L}$ & $\mathrm{P}$ & $\mathrm{L}$ & $\mathrm{P}$ & $\mathrm{L}$ & $\mathrm{P}$ & $\mathrm{L}$ & $P$ & $\mathrm{~L}$ & $\mathrm{P}$ & Total \\
\hline Pembel. Kelas Rangkap & 0 & 4 & 0 & 0 & 0 & 0 & 0 & 0 & 0 & 4 & 4 \\
\hline Pembel. IPS SD & 1 & 1 & 0 & 0 & 0 & 1 & 0 & 0 & 1 & 2 & 3 \\
\hline Pengelolaan Perpus & 0 & 5 & 0 & 0 & 0 & 0 & 0 & 2 & 0 & 7 & 7 \\
\hline Pembel PPKn & 0 & 2 & 0 & 0 & 0 & 0 & 0 & 0 & 0 & 2 & 2 \\
\hline Pembel. IPA di SD & 0 & 1 & 0 & 0 & 0 & 0 & 0 & 0 & 0 & 1 & 1 \\
\hline Met. Penel. Pend & 1 & 2 & 0 & 0 & 0 & 0 & 0 & 0 & 1 & 2 & 3 \\
\hline Met. Penel. Pend & 1 & 3 & 0 & 0 & 0 & 0 & 0 & 0 & 1 & 3 & 4 \\
\hline Evaluasi Pend & 3 & 20 & 0 & 0 & 0 & 0 & 0 & 0 & 3 & 20 & 23 \\
\hline Evaluasi Pend & 0 & 5 & 0 & 0 & 0 & 0 & 0 & 0 & 0 & 5 & 5 \\
\hline Teknik Penulisan KI & 2 & 6 & 0 & 0 & 1 & 0 & 0 & 0 & 3 & 6 & 9 \\
\hline Pend. Kewarganegaraan & 1 & 8 & 0 & 0 & 0 & 1 & 0 & 0 & 1 & 9 & 10 \\
\hline Geometri \& Penguk. & 0 & 1 & 0 & 0 & 0 & 0 & 0 & 0 & 0 & 1 & 1 \\
\hline Manajemen Kelas & 0 & 4 & 0 & 0 & 0 & 0 & 0 & 1 & 0 & 5 & 5 \\
\hline Pengemb. Pembel & 0 & 0 & 0 & 0 & 0 & 0 & 0 & 0 & 0 & 0 & 0 \\
\hline Pend. Inklusi di SD & 0 & 3 & 0 & 0 & 0 & 0 & 0 & 0 & 0 & 3 & 3 \\
\hline Sum & 9 & 65 & $\mathbf{0}$ & $\mathbf{0}$ & 1 & 2 & $\mathbf{0}$ & 3 & 10 & 70 & 80 \\
\hline Percentage (\%) & 11,25 & 81,25 & $\mathbf{0}$ & $\mathbf{0}$ & 1,25 & 2,5 & $\mathbf{0}$ & 3,75 & 12,5 & 87,5 & 100 \\
\hline
\end{tabular}

The data in the table above shows that there are 80 questions fall into low category. Of these the majority $(92.50 \%)$ are expressed by using the "what" question word. Overall, it can be said that out of 138 questions, more than half $(57.97 \%)$ of the questions asked by students are low-level questions, while the remaining $32.61 \%$ are high-level questions (Table 3 ).

Table 3. Distribution of High-Level Questions Asked by Students During Lectures

\begin{tabular}{c|cccc|ccc}
\hline Courses Name & \multicolumn{3}{|c|}{ Type of asked Questions } & \multicolumn{3}{c}{ Summary } \\
\hline & \multicolumn{2}{|c}{ Why } & \multicolumn{2}{c}{ How } & & & L \\
\hline & L & P & L & P & P & Total \\
\hline Pembel. Kelas Rangkap & 0 & 0 & 0 & 4 & 0 & 4 & 4 \\
Pembel. IPS SD & 0 & 0 & 0 & 0 & 0 & 0 & 0 \\
Pengelolaan Perpus & 0 & 0 & 0 & 2 & 0 & 2 & 2 \\
Pembel PPKn & 0 & 1 & 2 & 1 & 2 & 2 & 4 \\
Pembel. IPA di SD & 0 & 0 & 1 & 0 & 1 & 0 & 1 \\
Met. Penel. Pend & 0 & 0 & 0 & 1 & 0 & 1 & 1 \\
Met. Penel. Pend & 0 & 0 & 0 & 1 & 0 & 1 & 1 \\
Evaluasi Pend & 1 & 1 & 1 & 7 & 2 & 8 & 10 \\
Evaluasi Pend & 0 & 0 & 0 & 1 & 0 & 1 & 1 \\
Teknik Penulisan KI & 0 & 1 & 0 & 1 & 0 & 2 & 2 \\
Pend. Kewarganegaraan & 0 & 0 & 1 & 1 & 1 & 1 & 2 \\
Geometri \& Penguk. & 0 & 1 & 0 & 0 & 0 & 1 & 1 \\
Manajemen Kelas & 0 & 1 & 0 & 6 & 0 & 7 & 7 \\
Pengemb. Pembel & 0 & 1 & 1 & 2 & 1 & 3 & 4 \\
Pend. Inklusi di SD & 0 & 1 & 1 & 3 & 1 & 4 & 5 \\
\hline Sum & $\mathbf{1}$ & $\mathbf{7}$ & $\mathbf{7}$ & $\mathbf{3 0}$ & 8 & 37 & 45 \\
\hline Percentage (\%) & $\mathbf{2 , 2 2}$ & $\mathbf{1 5 , 5 6}$ & $\mathbf{1 5 , 5 6}$ & $\mathbf{6 6 , 6 7}$ & 17,78 & 82,22 & 100 \\
\hline
\end{tabular}

The data in table 3 shows that there are 45 highlevel questions asked by students. Most questions reached $66.67 \%$ submitted by using the question word "how".

\section{DISCUSSION}

Questions posed someone is an expression of curiosity about an information, either a way of solving problems or just want to know the incident, time, and place. To disclose information that students 
want in the course can be known from the type of questions asked. There are 5 types of questions according to Felder and Rebecca (2005), among other things the question "what" is asked to ask everything related to the content or subject matter. The "who" question to ask the people or parties involved. The "when" question to ask when the event occurred. The question "where" to ask where the event took place. The "why" question to ask why or why something happened. While the question "howhow" is used to ask how or the process of work something.

Based on the data collected, it was found that very many students were asking questions with the question "what". Of the total data of 138 questions, there are 74 questions $(53.62 \%)$ using the question word "what", while the second sequence with 37 questions $(26,81 \%)$ using the question word "how" and no students who ask with words Asked "who". The data illustrates that most students in the course tend to want information about "something" relating to the content or course material. This is in accordance with the opinion of Harrison and Salinger (2010) that students in following the course most are eager to obtain information about the material to be discussed. This type of question according to Irman (2008) including the type of sentence asked clarification (confirmation) and confirmation (clarification). This means that the question posed aims to establish and clarify information that has been owned or known. The types of questions that simply ask for confirmation with the question "what" in taxonomy Bloom (Anderson, et.al, 2001) included in knowledge question. Wartono (2003) explains that knowledge questions do not require students to think deeply. According to Ibtihal and Oqlah (2015), the questions belonging to the cognitive category only describe the information the students want to know about the material to be discussed and studied.

From the search results to the student's question, the findings, although using the question word "what" of the students do not just want information of knowledge superficially, but want more deeply to understand the material. Examples of questions asked other than the one asking: "What is the real example of educational goals ?; What is the complexity of the activity?". There is also a question "what is the influence of the application of socio-cultural foundation to education between cities and regions?". The example of the question explains that although the question both uses the "what" question but the information gained is just knowledge and some want to understand the relationship between variables leads to high level analysis or knowledge.

The next question type asked in large quantities is the "how" word. For example: "how to explain to elementary students about school and community relationships?"; "How to overcome various educational issues, especially regarding the weakness of education management?"; "How to do activities open and close learning effectively?". Taking into account the type of question posed with the question "how" above, when viewed from taxonomy of Bloom into the category of application or application (C3). According to Uno (2012: 57), the application is defined as a person's ability in using knowledge to solve various problems that arise in everyday life. When looking at the type of application questions above, it appears that some have led to the analysis. This means that students do not just ask about how to apply knowledge to the object factually, but already connect with other variables. From these findings indicate that the information that the student wants to know not only the knowledge aspect but has increased to the level of understanding, application concept, and analysis.

From the question asked by the students was not only able to reveal about the kind of information that students want to know. An interesting statement put forward by Sentanu (2007), that the quality of a person is largely determined by the quality of the question. This expression confirms that the types of questions that students ask can describe the quality of thinking of the students themselves.

The results of data acquisition illustrate the quality of student questions that vary, the types of questions there are just want to know a definition, but some are to the level of understanding, implementation, analysis, and even some have been in the direction of evaluation. Examples of questions asked include: "What if the teacher manual, less appropriate between KI, KD, and indicator?"; "In making the assessment format how to determine the BT level (Not Seen), MT (Start Visible), MB (Beginning Culture), SM (already Culture) to avoid confusion perception?". From the example of the question it appears that the students have been leading to a high level of evaluation (C5) because it has assessed and analyzed the linkage of $\mathrm{KI}, \mathrm{KD}$, and Indicators and criteria of assessment in the attitude aspect?.

Based on the data collected and classified obtained the distribution of data include $57.96 \%$ of the questions asked by students in the lecture included in the low category with the type of question "what, where, and when" and 32.61\% of questions asked by students including high category with Using the question word "why and how". In addition there are $9.42 \%$ of students who ask questions but do not use the word question but use the word command. For example: "please specify the model and form of a special needs child service!", "Please explain what is meant by the differentiating power of the problem and give an example!", "Explain the criteria of empirical validity and what are the criteria of empirical validity?". This fact proves that there are still students who do not understand the task given by the lecturer or have not been able to distinguish between the word question with the word command. Yet when viewed from the 
intent of someone asking a question, in fact it can be delivered in the form of a question of demand (compliance question). This type of question implies a question that expects someone to obey the command spoken in the form of a question. How to change the sentence of the command into a question sentence. For example: "Can you name the model and form of child care with special needs?", "What is empirical validity? What is the criterion of empirical validity?.

The data above reflects that the quality of student inquiries still needs to be improved, since there are still quite a lot of questions that fall into low quality. Rocca (2010) states that the quality of a person is represented by the questions that arise. Questions also represent how deep a person's knowledge is and how deep his curiosity is and how high his logic is.

Humans are individual beings. Each individual represents a different character from one another (Radovan and Makovec, 2015). This can be observed from the courage in asking questions or answering them. Similarly, between men and women. From the data collection, the types of questions asked by men and women are obtained by the fact that there are differences in asking questions. Most of the lowgrade questions were raised by female students. Similarly, the submission of questions without using the word question but with the word "command" is also all submitted by female students. In terms of high-level inquiries between male students and female students look balanced and not much different in number.

\section{CONCLUSION}

Based on the findings and discussion, it can be concluded that the most asked question type is "what" reaches 74 questions $(53,62 \%)$, followed by "how" reach 26,81\% (37 questions). Another interesting finding is that there are still students who were asked to ask questions but did not ask questions but instead ordered or ordered the group to explain something to be known and the number reached $9.42 \%$, all submitted by female students.

The level of thinking ability in terms of the types of questions asked varies. Overall it can be said that out of 138 questions, more than half (57.97\%) are low-level questions and $32.61 \%$ are high-level questions. Low-level questioning is dominated by the use of the "what" question reaches $92.50 \%$ of all lowlevel questions and $81.25 \%$ of which are proposed by female students. While high-level questions reached 45 of 138 questions. Most of the questions asked "how" reached $82.23 \%$ and the rest use the question word "why".

There is a difference in asking questions between men and women. Most low-level questions are asked by female students. Asking questions without using the word question but with the word "command" is also all submitted by female students. For high-level inquiries between male students and female students look balanced and not much different in number.

\section{SUGGESTION}

With reference to findings and conclusions, it is advisable to lecturers to use varied strategies in giving students an opportunity to ask questions. For example giving additional points value of each student who asks. Students who ask questions are generally fixed, ie students who have the confidence and courage. For that other students also dare to ask questions, need to be given the opportunity to ask in writing. The findings on the quality of student inquiries are still relatively low, as more questions reveal the knowledge and understanding aspects than the higher level questions. It is therefore suggested that lecturers in addition to answering student questions, also need to give examples of the use of high-level questions and productive questions that require answers through verification.

\section{REFERENCES}

[1] Anderson, L.W., Krathwohl D.R., Airasian, P.W., Cruikshank, K.A., Mayer, R.E., Pintrich, P.R., Raths, J., Wittrock, M.C. Eds. (2001). Taxonomy for Learning, Teaching, and Assessing: A revision of Bloom's Taxonomy of Educational Objectives. New York: Addition Wesley Longman Inc.

[2] Cunningham, R.T. 1971. Developing Question Asking Skill. London: Methues.

[3] Elstgeest, J. (1987). The Right Question at The Right Time. Harlen W. (Ed.) Take The Plunge. (hlm. 36-45). London: Heinemann Educational Books.

[4] Felder, R. M. and Rebecca B. (2010). Understanding Student Differences. Journal of Engineering Education 94(1): 57-72

[5] Harrison, C. and Salinger T, Assessing Reading 1: Theory and Practice: USA: Routledge, 1998, p. 89.

[6] Ibihal, R. A. And Oqlah M. S. (2015). Using Bloom's Taxonomy to Evaluate the Cognitive Levels of Master Class Textbook's Questions. English Language Teaching J. 8(5): 100-110

[7] Irman, Muhammad. (2008). Bahasa Indonesia 1. untuk SMK/MAK Semua Program Keahlian Kelas X, Jakarta : Pusat perbukuan Departemen Pendidikan Nasional.

[8] Kartini, H, dkk. (2003). Peningkatan Kemampuan Bertanya Siswa SD dalam Pembelajaran IPA Melalui Penerapan Model Interaktif (penelitian Tindakan Kelas di SDN Sawojajar V Kec. Kedungkandang Kota Malang)

[9] Kementerian Pendidikan dan Kebudayaan. (2013). Panduan Teknis: Pembelajaran Tematik 
Terpadu dengan Pendekatan Saintifik di SD. Jakarta: Kemendikbud.

[10]Majid, A. (2014). Pembelajaran tematik Terpadu. Bandung: PT. Remaja Rosdakarya.

[11] Radovan, M. And Makovec D. (2015). Relations between Students Motivation and Perceptions of Learning Environment. Center for Educational Policy Studies Journal. 5(2): 115-138

[12]Rocca, Kelly A. 2010. Student Participation in the College Classroom: An Extended Multidicipinary Literature Review. Communication Education 59:2 (185-213)
[13] Sentanu, E. 2007. Quantum Ikhlas: Teknologi Aktivasi Kekuatan Hati. Jakarta: Elex Media Komputindo.

[14]Uno, Hamzah B., dan Nurdin M., 2012. Belajar dengan pendekatan PAILKEM (Pembelajaran Aktif Innovatif Lingkungan Kreatif Efektif Menarik). Jakarta: Bumi Aksara.

[15]Usman, M.U. 2002. Menjadi Guru Profesional. Bandung: Penerbit P.T. Remaja Rosdakarya.

[16] Wartono. 2003. Keterampilan Dasar Mengajar. Malang: Universitas Kanjuruhan Malang. 